the group. Consequently, by choosing a complete set of vibrational symmetry co-ordinates which transform according to irreducible representations of the group of symmetry, there may be obtained at once, by application of Schur's Lemma, the most general form of the matrix of the potential energy.

This was illustrated by the example of the methane molecule.

Thus, if the methane molecule is a regular tetrahedron, the potential energy has five general force constants and the molecule has four different vibrational frequencies. Similarly, if the molecule has the form of a square pyramid, the group is $C_{4} v$, the vibrations are $2 A_{1}+B_{1}+2 B_{2}+2 E_{1}$, there are seven different frequencies and ten general force constants. Experimentally four frequencies are found, and the molecule has the form of a regular tetrahedron.

Dr. C. A. Coulson (University College, Dundee) discussed the theory of the carbon-carbon linkages in some simple polyenes and aromatic molecules. Certain hydrocarbons can be adequately described by a single structural formula. Examples are ethane, where the linkage is a single bond, ethylene, where the linkage is a double bond, and acetylene, where the linkage is a triple bond. Other molecules, such as benzene, naphthalene and butadiene, are more complex, and in these cases the linkages must be considered to be of fractional order. General methcds of calculating the orders of these linkages have been discovered. They evaluate the energy of a linkage by the approximation of molecular orbitals or of electron pairs, in terms of a single parameter which measures the difference of energy of the single and double bonds. Linear interpolation then gives the order.

From the experimental values of certain physical constants of the single, double and triple bonds, empirical curves may be constructed. These may be used to predict values for the linkages of intermediate order. Thus, the benzene linkage is of order $1 \cdot 65$, and the internuclear distance should be $1.39 \mathrm{~A}$., in exact agreement with direct observation. Similarly, in naphthalene, there should be four types of linkage. Their orders, beginning at the central link and working outwards, are $1 \cdot 52,1 \cdot 56,1 \cdot 76,1 \cdot 60$. The corresponding lengths are $1 \cdot 42,1 \cdot 40,1 \cdot 38,1 \cdot 40 \mathrm{~A}$.

Mr. G. J. Kynch (Imperial College, London) discussed the relations between the magnetic properties, specific heat and absorption spectra of rare earth crystals. The deviations of the principal and mean susceptibilities from Curie's law, $\chi T=$ constant, are caused by an electric crystalline field which perturbs the magnetic ion. Calculations of the mag. netic susceptibilities involve the determination of the lowest energy levels of the magnetic ion. These can be compared with those obtained from the measurements of the absorption spectra and the specific heat. Previously, it was thought that a fourth order cubic field would correlate all the data. This no longer seems possible, because of the considerable magnetic anisotropy of the crystals. A new interpretation of the levels found spectroscopically must be sought.

\title{
The British Rhætic Flora
}

DROF. T. M. HARRIS, with experience of the Greenland Rhætic flora behind him, has now studied the British Rhætic beds and, with the application of new methods, described with considerable detail some of the few plants from these rocks (The British Rhætic Flora, British Museum, 1938.) The main outcrop of Rhætic rocks extends from Dorset to north Yorkshire, and it is from these alone that plant remains have been obtained, though smaller outcrops also occur in Wales, Northern Ireland and Scotland. The conception of the Rhætic formation is that of a shallow sea, dotted with islands, and in this, slight changes in level isolated lagoons, which would soon become brackish or freshwater lakes. It is probably in such lakes that the plants grew. The plant-containing beds occur as strata between those containing fish and other marine remains, suggesting temporary incursions of the sea into the lagoon region. The Bristol locality seems to have supplied most of the specimens.

A new method of examination of surface features by reflected light on specimens moistened with paraffin oil has contributed materially to the success of the investigation. The usual methods of rock sections and cellulose nitrate films have also been used; but are difficult with this material.

A common plant is the alga Botryococcus braunii, recognizable as colonies, terra-cotta in colour and with characteristic resistance to $\mathrm{HNO}_{3}+\mathrm{KClO}_{3}$. It is probable that this fossil is the same plant which has been described under various names from Ordo. vician, Carboniferous, Permian, Rhætic, Jurassic and other rocks up to the present day.

Another alga has close resemblance to Cosmarium; but owing to failure to recognize sculpturing of the wall, it is provisionally distinguished as Stenixys cosmarioides.

Perhaps the most interesting plant and one described in amazing detail is Naiadita lanceolata, an undoubted bryophyte. Earlier records of Bryophyta are very scanty and only allow the statement that liverworts, probably belonging to the Jungermanniales, extend back to the Carboniferous, whilst records of mosses are more doubtful.

Naiadota is now described with details of stem and leaf form and structure, rhizoids, gemmæ (free and possibly in gemmæ cups, and development of new plantules from gemmæ), archegonia, sporophytes, perianth and spores. The plant is thus sufficiently known to compare with present-day genera. The radial construction and spiral phyllotaxis $(3 / 8)$ are moss-like features; but the majority of the characters place it in the Hepaticæ, and provisionally as nearest to the Riellaceæ of the Sphærocarpales.

Prof. Harris discusses the conceptions of evolutionary trend in Bryophyta and regards Naiadita as supporting rather the view of a reduction series than an up-grade series.

One other plant, Hepaticites solenotus, appears to be a hepatic resembling Aneura.

Certain other fossils, previously described as Rhætic, seem more correctly to be Liassic. 